\title{
Pengaruh Technology Acceptance Model Dan Digital taxation Terhadap Kepatuhan Wajib Pajak Dengan Pemahaman Internet Sebagai Variabel Moderating
}

\author{
Sihar Tambun \\ sihar.tambun@gmail.com \\ FEB Universitas 17 Agustus 1945 Jakarta \\ Riris Rotua Sitorus \\ riris.sito@gmail.com \\ FEB Universitas 17 Agustus 1945 Jakarta \\ Tania Alvianita Pramudya \\ alvianitania.1412@gmail.com \\ FEB Universitas 17 Agustus 1945 Jakarta
}

\begin{abstract}
This study aims to determine the effect of the Technology Acceptance Model and Digital taxation on Tax Compliance with Internet Understanding as a moderating variable. The method used in this research is multiple regression analysis and moderating calculations using the interaction method. Processing questionnaire data using Smart PLS application. The sample in this study consisted of 94 individual taxpayers who ran businesses or had free work in North Jakarta. The results of this study indicate that the Technology Acceptance Model and Digital taxation have no significant effect on tax compliance. Internet Understanding has a significant positive effect on Tax Compliance. Moderation of Internet Understanding on the influence of Technology Acceptance Model has a significant positive effect on tax compliance. Moderation of internet understanding on the influence of digital taxation has a significant positive effect on Tax Compliance.
\end{abstract}

Keywords : Technology Acceptance Model, Digital Taxation, Taxpayer Compliance, Internet Understanding

\begin{abstract}
ABSTRAK
Penelitian ini bertujuan untuk mengetahui perngaruh dari Technology Acceptance Model dan Digital taxation terhadap Kepatuhan wajib pajak dengan Pemahaman Internet sebagai variabel moderating. Metode yang digunakan dalam penelitian ini adalah analisis regresi berganda dan perhitungan moderating menggunakan metode interaksi. Mengolah data dengan menggunakan bantuan aplikasi Smart PLS. Adapun sampel dalam penelitian ini terdiri dari 94 Wajib Pajak Orang Pribadi yang menjalankan usaha atau memiliki pekerjaan bebas di Jakarta Utara. Hasil penelitian ini menunjukkan bahwa Technology Acceptance Model dan Digital taxation tidak berpengaruh signifikan terhadap Kepatuhan wajib pajak. Pemahaman Internet berpengaruh signifikan positif terhadap Kepatuhan wajib pajak. Moderasi Pemahaman Internet atas pengaruh Technology Acceptance Model berpengaruh signifikan positif terhadap Kepatuhan wajib pajak. Moderasi Pemahaman Internet atas pengaruh Digital taxation berpengaruh signifikan negatif terhadap Kepatuhan wajib pajak.
\end{abstract}

Kata Kunci : Model Teknologi Penerimaan, Perpajakan Digital, Kepatuhan Wajib Pajak , Pemahaman Internet 


\section{PENDAHULUAN}

Pajak merupakan aspek penerimaan terbesar negara. Komposisi penerimaan pajak pada postur APBN mencapai lebih dari 70\%. Oleh karena itu, Direktorat Jenderal Pajak (DJP) sebagai instansi pemerintah di bidang administrasi perpajakan bertugas untuk mengamankan Anggaran Pendapatan dan Belanja Negara (APBN) terutama pada sektor penerimaan perpajakan. Dalam menjalankan tugasnya, DJP dibiayai oleh APBN dengan tujuan untuk memenuhi APBN dari penerimaan pajak. Persentase pencapaian pajak pada tahun 2018 mencapai 92,24\%. Capaian ini lebih tinggi dibandingkan tahun 2017. Bahkan capaian ini merupakan yang tertinggi dalam 5 tahun terakhir. (Kementrian Keuangan Republik Indonesia, 2018). Kemudian capaian realisasi penerimaan pajak periode tahun 2014 sampai 2018:

\section{Gambar 1. Realisasi Penerimaan Pajak}

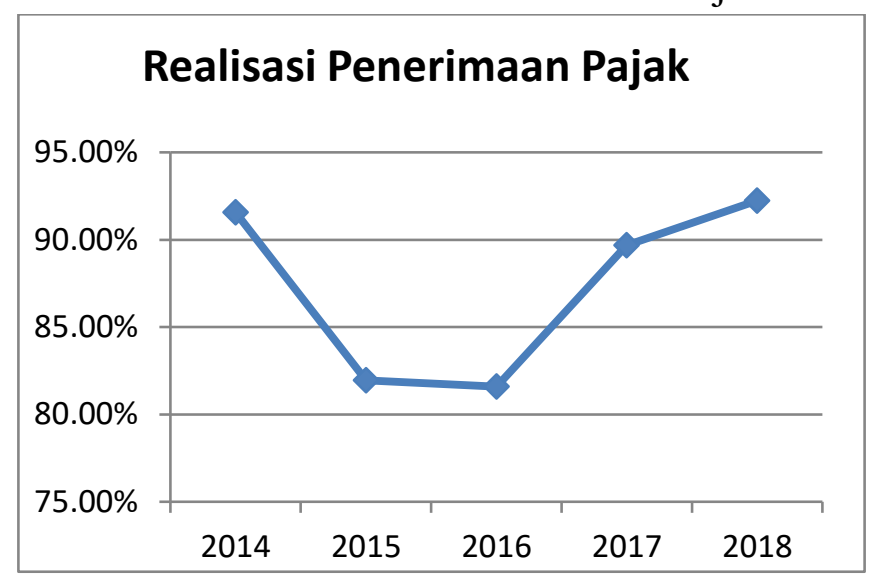

Sumber : Otoritas Jasa Keuangan, 2019

Untuk mencapai persentase capaian penerimaan pajak yang tinggi tentunya diperlukan kerjasama dari berbagai pihak, termasuk kepatuhan masyarakat Indonesia sebagai Wajib Pajak. Kepatuhan perpajakan masyarakat Indonesia semakin tahun semakin membaik. Hal ini dibuktikan dengan pertumbuhan pada tingkat penyampaian Surat Pemberitahuan Tahunan Pajak Penghasilan (SPT PPh) yang hingga 31 Maret 2018 telah masuk sebanyak 10,59 juta SPT, atau naik 14\% dibandingkan periode yang sama tahun 2017 (Kementrian Keuangan Republik Indonesia, 2018).

Tabel 1. Jumlah Wajib Pajak

\begin{tabular}{|l|l|l|l|l|l|}
\hline Jumlah Wajib Pajak & 2018 & 2017 & 2016 & 2015 & 2014 \\
\hline Terdaftar & 38.651 .881 & 39.151 .603 & 36.398 .089 & 33.313 .655 & 30.298 .738 \\
\hline $\begin{array}{l}\text { Wajib menyampaikan } \\
\text { SPT }\end{array}$ & 17.653 .963 & 16.598 .887 & 20.165 .718 & 18.159 .840 & 18.357 .833 \\
\hline $\begin{array}{l}\text { Telah menyampaikan } \\
\text { SPT }\end{array}$ & 10.589 .648 & 12.057 .400 & 12.256 .401 & 10.975 .909 & 10.854 .819 \\
\hline
\end{tabular}

Sumber : Otoritas Jasa Keuangan, 2019

Jumlah Wajib Pajak yang terdaftar atau memiliki NPWP saat ini adalah sebanyak 38.651.881 dengan 17.653.963 diantaranya wajib menyampaikan SPT. Namun hingga saat ini yang telah menyampaikan SPT tahun pajak 2017 adalah 10.589.648 atau baru 59,98\% dari jumlah tersebut. 
Walaupun demikian, terjadi peningkatan signifikan sebesar 30,5\% pada jumlah penyampaian SPT Tahunan Non-Karyawan (formulir 1770), sedangkan jumlah SPT Tahunan Karyawan 1770 S dan 1770 S terjadi kenaikan sebesar 12,4\%. Jumlah penyampaian SPT Elektronik sampai dengan tanggal 31 Desember 2018 sebanyak 5.800.480 SPT dari Jumlah sasaran WP yg telah ditetapkan sebesar 6.299.742. Realisasi sampai dengan tahun 2018 berakhir adalah sebesar 85,55\% penyampaian SPT melalui e-Filing dari target s.d 31 Desember 2018 sebesar 82\% (Kementrian Keuangan Republik Indonesia, 2018).

Tabel 2. Kepatuhan Wajib Pajak

\begin{tabular}{|c|c|c|c|c|c|}
\hline Indikator & $\mathbf{2 0 1 5}$ & $\mathbf{2 0 1 6}$ & $\mathbf{2 0 1 7}$ & $\mathbf{2 0 1 8}$ & $\mathbf{2 0 1 9}$ \\
\hline Tax Ratio & $13,2 \%$ & $14,2 \%$ & $14,6 \%$ & $15,2 \%$ & $16,0 \%$ \\
\hline Penerimaan Pajak & $\begin{array}{c}1.294 \\
\mathrm{~T}\end{array}$ & $\begin{array}{c}1.512 \\
\mathrm{~T}\end{array}$ & $\begin{array}{c}1.737 \\
\mathrm{~T}\end{array}$ & $\begin{array}{c}2.007 \\
\mathrm{~T}\end{array}$ & $\begin{array}{c}2.329 \\
\mathrm{~T}\end{array}$ \\
\hline $\begin{array}{c}\text { SPT melalui e- } \\
\text { filling }\end{array}$ & 2 juta & 7 juta & 14 juta & 18 juta & 24 juta \\
\hline $\begin{array}{c}\text { Jumlah WP } \\
\text { terdaftar }\end{array}$ & 32 juta & 36 juta & 40 juta & 42 juta & 44 juta \\
\hline
\end{tabular}

Sumber : Otoritas Jasa Keuangan, 2019

Minat masyarakat di tahun 2018, semakin tinggi dalam menggunakan SPT elektronik. Hal ini ditunjukkan dengan pertumbuhan 21,6\% pada jumlah SPT yang disampaikan secara elektronik yang mencapai 8,49 juta SPT atau $80,13 \%$ dari seluruh SPT yang dilaporkan. Sedangkan oenyampaian SPT secara manual turun $12 \%$. Salah satu tindakan yang dilakukan pemerintah untuk meningkatkan persentase penyampaian SPT melalui e-filling adalah dengan menambah server DJP Online, e-filling, dan e-form (Kementrian Keuangan Republik Indonesia, 2018). Data data ini menjadi fenomena yang sangat menarik untuk diteliti. Kombinasi teknologi dan digitalisasi berkesempatan besar untuk mendukung peningkatan kepatuhan wajib pajak. Tentunya wajib pajak harus menguasai teknologi dan internet supaya bisa melaporkan aktivitas perpajakannya secara online dan menggunakan fasilitas layanan pajak secara online.

\section{LITERATUR REVIEW DAN HIPOTESIS}

\section{Teori Perilaku Terencana}

Teori Perilaku Terencana (Theory of Planned Behavior) awal mulanya berasal dari Teori Perilaku Beralasan (Theory of Reasoned Action). Teori Perilaku Terencana adalah sebuah teori yang menjelaskan hubungan antara keyakinan dan perilaku. (Wahyono, 2014) Teori ini menyatakan bahwa Sikap (Attitide), Norma Subjektif (Subjective norm), dan Persepsi Kontrol Perilaku (Perceived Behavioral Control) bersama-sama membentuk Niat (Intention) dan Perilaku (Behavior) individu (Lo Choi Tung, 2011). Persepsi kontrol perilaku berasal dari teori self-efficacy (SET). Self-Efficacy adalah prasyarat yang paling penting untuk perubahan perilaku, karena menentukan inisiasi perilaku koping. Teori self-efficacy memberikan kontrubusi untuk menjelaskan berrbagai hubungan antara keyakinan, sikap, niat, dan perilaku (Pertiwi, 2016). Adapun kelebihan dari Teori Perilaku Terencana adalah membantu 
memprediksi (meningkatkan prediktabilitas) niat perilaku seseorang. Teori ini dapat menjelaskan perilaku sosial individu dengan mempertimbangkan norma sosial sebagai variabel penting. Sedangkan kelemahan dari Teori Perilaku Terencana adalah perilaku kesehatan individu dipengaruhi oleh emosi pribadi mereka dan alam mempengaruhi sarat, ini adalah kelemahan yang menentukan untuk memprediksikan perilaku yang berhubungan (Pertiwi, 2016). Teori Perilaku Terencana adalah salah satu model psikologi sosial yang paling sering digunakan untuk meramalkan perilaku dan merupakan prediksi perilaku yang baik karena diseimbangkan oleh niat untuk melaksanakan perilaku. Atas dasar inilah yang menjadikan motivasi kedua peneliti memilih untuk menggunakan Teori Perilaku Terencana dalam menjelaskan fenomena atau faktor yang memengaruhi kepatuhan wajib pajak di DKI Jakarta. Dalam Teori Perilaku Terencana, perilaku yang ditampilkan oleh wajib pajak timbul karena adanya niat untuk berperilaku. Munculnya niat berperilaku ditentukan oleh tiga faktor penentu, yaitu: sikap terhadap perilaku; norma subjektif; dan kontrol perilaku yang dipersepsikan.

\section{Technology acceptance model}

Technology acceptance model adalah salah satu model yang biasa digunakan untuk menganalisis faktor yang mempengaruhi diterima atau tidaknya suatu sistem informasi. Model yang diperkenalkan pertama kali oleh Fred Davis pada 1986 ini merupakan hasil pengembangan dari Theory of Reasoned Action (TRA). Adapun TAM bertujuan untuk menjelaskan dan memperkirakan tingkat penerimaan pengguna terhadap suatu sistem informasi. Selain itu, TAM juga menyediakan suatu basis teoritis untuk mengetahui faktorfaktor yang mempengaruhi penerimaan terhadap suatu teknologi, serta menjelaskan hubungan sebab akibat antara keyakinan dan perilaku, tujuan/ keperluan, dan penggunaan/user suatu sistem informasi. (idtesis.com, 2018) Tingginya penggunaan suatu sistem informasi menandakan bahwa suatu sistem informasi bermanfaat dan mudah untuk digunakan. Seseorang akan memanfaatkan sistem informasi dengan alasan bahwa sistem tersebut akan menghasilkan manfaat bagi dirinya. (Hestanto) Ada 3 faktor yang mempengaruhi penggunaan sebuah sistem, yaitu Perceived Usefulness, Perceived Ease of Use, dan Intention to Use. Perceived Usefulness adalah suatu tingkatan dimana seseorang percaya bahwa menggunakan sistem tersebut dapat meningkatkan kinerjanya dalam bekerja. Perceived Ease of Use adalah suatu tingkatan dimana seseorang percaya bahwa menggunakan sistem tersebut mempermudah kinerjanya dalam bekerja. Intention to Use adalah kecenderungan perilaku pengguna sistem untuk menggunakan suatu teknologi. Berbagai penelitian telah menggunakan TAM dan menunjukkan bahwa TAM adalah model yang valid untuk menguji suatu sistem informasi (BINUS, 2016).

\section{Digital taxation}

Digitalisasi adalah mengubah banyak aspek dari kehidupan kita sehari-hari, serta cara ekonomi dan masyarakat kita diatur. Luasnya dan kecepatan perubahan yang dibawa oleh transformasi digital adalah penting dan menimbulkan sejumlah besar tantangan kebijakan publik, termasuk pajak. Digitalisasi memiliki berbagai implikasi untuk perpajakan. Digitalisasi berdampak pada kebijakan dan administrasi perpajakan baik di tingkat domestik dan internasional, menawarkan alat-alat baru, sekaligus memperkenalkan tantangan baru (Project et al., 2020). Direktorat Jenderal Pajak (DJP) sebagai administrator perpajakan Indonesia juga mengalami tantangan disrupsi (gangguan) digital dalam memperbaiki infrastruktur teknologi perpajakan. Langkah 
reformasi dalam teknologi informasi diwujudkan salah satunya melalui pengembangan core tax system DJP maupun sistem pendukung lainnya (Sejati, 2019). E-Filing adalah suatu cara pelaporan SPT Pajak yang dilakukan secara online atau elektronik melalui website Direktorat Jenderal Pajak (DJP Online) ataupun melalui saluran e-Filing resmi lain yang ditetapkan pemerintah sesuai dengan peraturan perundang-undangan. Jika dibandingkan dengan pelaporan pajak manual, e-Filing pajak memberikan banyak keuntungan seperti lapor pajak online dari mana saja dan kapan saja, hemat waktu, serta bukti pelaporan disimpan lebih aman dan mudah dilacak, tanpa khawatir hilang atau terselip. Agar dapat melakukan e-Filing, berikut ini syarat yang harus dimiliki adalah EFIN/nomor identitas elektronik, dokumen elektronik/SPT elektronik, akses ke web e-Filing/sudah terdaftar di OnlinePajak. (ONLINEPAJAK, 2018)

\section{Kepatuhan wajib pajak}

Menurut Safri Nurmanto dalam Siti Kurnia Rahayu (2010:138) mengatakan bahwa kepatuhan perpajakan dapat didefinisikan sebagai sutau keadaan di mana Wajib Pajak memenuhi semua kewajiban perpajakan dan melaksanakan hak perpajakannya. Kewajiban dan hak perpajakan menurut Safri Nurmantu dibagi menjadi 2 kepatuhan, meliputi kepatuhan formal dan kepatuhan material. Kepatuhan formal adalah kepatuhan Wajib Pajak terhadap aturan formal perpajakan sesuai dengan ketentuan dalam undang-undang perpajakan seperti, mendaftarkan diri dan memiliki NPWP, Menghitung dan membayar pajak terutang, serta melaporkan SPT nya (baik SPT Masa maupun SPT Tahunan). Contoh dari kepatuhan formal misalnya, ketentuan batas waktu penyampaian Surat Pemberitahuan Pajak Penghasilan (SPT PPh) Tahunan tanggal 31 maret. Apabila Wajib Pajak telah melaporkan SPT PPh tahunan sebelum atau pada tanggal 31 maret, maka Wajib Pajak telah memenuhi ketentuan formal, namun isinya belum tentu memenuhi ketentuan material. Kepatuhan material adalah kepatuhan Wajib Pajak secara subtantif/hakikatnya memenuhi semua ketentuan material perpajakan yaitu sesuai isi dan jiwa undang-undang pajak kepatuhan material juga dapat meliputi kepatuhan formal (pajaktaxes.blogspot, 2015). Jadi, kepatuhan material dapat meliputi kepatuhan formal, tetapi kepatuhan formal belum tentu mematuhi kepatuhan material. Wajib pajak yang memenuhi kepatuhan material adalah Wajib Pajak yang mengisi SPT dengan jujur, lengkap, dan benar sesuai ketentuan dan menyampaikannya ke KPP sebelum batas waktu akhir (pajaktaxes.blogspot, 2015).

\section{Pemahaman Internet}

Internet adalah sistem informasi global berbasis komputer. Internet merupakan jaringan komputer yang saling terkoneksi. Tiap jaringan komputer dapat mencakup puluhan, ratusan bahkan ribuan komputer, dan memungkinkan mereka untuk berbagi informasi satu dengan yang lain dan untuk berbagi sumbersumber daya komputerisasi seperti superkomputer yang kuat dan database informasi. Pemahaman memiliki kata dasar paham yang berarti pandai dan mengerti benar proses, cara, perbuatan. Berdasarkan penjelasan tersebut dapat diambil kesimpulan pemahaman internet adalah mengerti benar tentang apa itu internet dan mengetahui bagaimana cara menggunakan internet. (Oktaviani et al., 2018)

\section{Pengaruh Technology acceptance model terhadap Kepatuhan wajib pajak}


Menurut penelitian Karmila (2016) tentang "Pengaruh Tam Terhadap Kepatuhan Wajib Pajak Dengan Penggunaan E-Filing Sebagai Variabel Intervening Pada Kpp Pratama Sukoharjo” dapat disimpulkan bahwa persepsi kebermanfaatan, persepsi kemudahan dan pengguna e-filing masing - masing berpengaruh terhadap tingkat kepatuhan wajib pajak. Dalam penelitian ini pengguna e-filing menjadi perantara yang menghubungkan persepsi kebermanfaatan dan persepsi kemudahan terhadap kepatuhan wajib pajak. Dengan kata lain secara tidak langsung teori TAM (Persepsi Kebermanfaatan dan Persepsi Kemudahan) berpengaruh terhadap kepatuham wajib pajak melalui pengguna e-filing. Menurut penelitian Sari et al (2014) diperoleh hasil manfaat kegunaan sistem (usefulness), persepsi kemudahan penggunaan (ease of use) dan kondisi yang memfasilitasi (facilitating conditions) secara simultan memiliki pengaruh yang signifikan terhadap kepatuhan wajib pajak badan dengan kata lain penerapan TAM berpengaruh terhadap kepatuhan wajib pajak badan. Menurut penelitian Sudrajat \& Ompusunggu (2015) dapat ditarik kesimpulan bahwa pemanfaatan Teknologi Informasi memiliki pengaruh positif dan signifikan terhadap Kepatuhan Wajib Pajak. Berdasarkan hasil penelitian terdahulu di atas, maka ditetapkan hipotesis sebagai berikut, $\mathrm{H}_{1}$ : Terdapat pengaruh signifikan dari variabel Technology acceptance model terhadap Kepatuhan wajib pajak

\section{Pengaruh Digital taxation terhadap Kepatuhan wajib pajak}

Menurut penelitian Ersania \& Merkusiwati (2018) menunjukkan penerapan e-Registration, eBilling, dan e-Filling berpengaruh positif terhadap kepatuhan wajib pajak orang pribadi di KPP Pratama Denpasar Timur. Penelitian Handayani \& Tambun (2016) menyatakan bahwa penerapan teknologi harus didukung oleh pengetahuan yang baik dari wajib pajak. Semakin tinggi penerapan e-Registration, e-Billing, dan e-Filling maka kepatuhan wajib pajak juga akan semakin meningkat. Menurut penelitian Sarunan (2015) menunjukkan bahwa penerapan modernisasi sistem administrasi perpajakan pada Kantor Pelayanan Pajak Pratama Manado mempunyai pengaruh yang positif dan signifikan terhadap kepatuhan wajib pajak orang pribadi dan wajib pajak badan. Penelitian Tambun \& Kopong (2017) dan Tambun \& Witriyanto (2016) membuktikan bahwa e-filing berdampak signifikan terhadap kepatuhan wajib pajak. Berdasarkan hasil penelitian terdahulu di atas, maka ditetapkan hipotesis sebagai berikut, $\mathrm{H}_{2}$ : Terdapat pengaruh signifikan dari variabel Digital taxation terhadap Kepatuhan wajib pajak

\section{Pengaruh Pemahaman Internet terhadap Kepatuhan wajib pajak}

Menurut penelitian Istianita (2016) menyatakan bahwa Pemahaman Internet memiliki pengaruh positif serta signifikan terhadap Kepatuhan Wajib Pajak. Berdasarkan hasil penelitian terdahulu di atas, maka ditetapkan hipotesis sebagai berikut, $\mathrm{H}_{3}$ : Terdapat pengaruh signifikan dari Pemahaman Internet terhadap Kepatuhan wajib pajak

\section{Moderasi Pemahaman Internet atas Pengaruh Technology acceptance model terhadap Kepatuhan wajib pajak}

Teori TAM menjelaskan mengenai bagaimana suatu pengguna teknologi dapat menerima suatu sistem. Salah satu variabel dalam TAM adalah persepsi kemanfaatan (Perceived usefulness). Wajib Pajak yang beranggapan bahwa menggunakan e filling itu mudah akan mendorong mereka untuk semakin patuh dalam menjalankan kewajiban perpajakannya. Untuk dpat menggunakan e-filling, Wajib Pajak dituntut untuk paham mengenai cara mengoperasikan 
internet. Hal ini sejalan dengan penelitian Ngurah \& Putra (2019) menunjukkan terdapat Pemahaman Internet dapat memoderasi pengaruh Penerapan Sistem Efilling terhadap Kepatuhan Wajib Pajak. Berdasarkan hasil penelitian terdahulu di atas, maka ditetapkan hipotesis sebagai berikut, $\mathrm{H}_{4}$ : Pemahaman Internet mampu memoderasi pengaruh dari Technology acceptance model terhadap Kepatuhan wajib pajak

\section{Moderasi Pemahaman Internet atas Pengaruh Digital taxation terhadap Kepatuhan wajib pajak}

Menurut penelitian Mendra (2017) menyatakan bahwa Pemahaman Internet dapat memoderasi (memperkuat) pengaruh Penerapan Sistem E-filing terhadap Kepatuhan Wajib Pajak. Semakin baik Pemahaman Internet yang dimiliki Wajib Pajak akan mendorong Wajib Pajak untuk menggunakan sistem e-filing sehingga semakin meningkatkan Kepatuhan Wajib Pajak. Berdasarkan hasil penelitian terdahulu di atas, maka ditetapkan hipotesis sebagai berikut, $\mathrm{H}_{5}$ : Pemahaman Internet mampu memoderasi pengaruh dari Digital taxation terhadap Kepatuhan wajib pajak

\section{METODE PENELITIAN}

\section{Populasi dan Sampel}

Populasi dalam penelitian ini adalah Wajib Pajak Orang Pribadi yang menjalankan usaha atau memiliki pekerjaan bebas. Sedangkan sampel dalam penelitian ini adalah Adapun jumlah sampel dalam penelitian ini adalah 94 responden yang berada di Jakarta Utara yang akan dilakukan dengan metode purposive sampling yaitu dilakukan dengan mengambil sampel dari populasi berdasarkan suatu kriteria tertentu.

\section{Pengukuran Variabel}

Berdasarkan Undang-undang KUP, indikator kepatuhan wajib pajak adalah aspek ketepatan waktu pelaporan SPT, aspek pendapatan yang dilaporkan sesuai dengan ketentuan yang berlaku, dan tagihan pajak (STP/SKP) dibayar sebelum jatuh tempo (Sarunan, 2015). Indikator dari digital taxation adalah online portal \& digital tax system, digital tax policy, future strategis on digital taxation (Pemerathna, 2017). Menurut Wahyudi (2009), indikator dari TAM adalah kemudahan untuk digunakan (Perceived Ease of Use), mempertinggi efektifitas dan meningkatkan efisiensi (Perceived Usefulness), Motivasi tetap menggunakan (Intention to Use). Internet memberikan beberapa manfaat bagi kehidupan sehari-hari, diantaranya memperoleh informasi, menambah pengetahuan, dan kecepatan mengakses. Ketiga manfaat tersebut digunakan sebagai indikator, sebagai dasar untuk pengukuran Pemahaman Internet. (Lado \& Budiantara, 2018)

\section{Metode Analisis}

Proses analisa data akan dilakukan dengan menggunakan alat bantu software Partial Least Square (PLS). Validitas berasal dari bahasa Inggris yaitu validity yang mempunyai arti sejauh mana ketepatan dan kecermatan suatu alat ukur dalam melakukam fungsi ukurannya (Azwar, 1986). Uji validitas adalah suatu pengujian yang digunakan untuk menunjukkan sejauh mana 
alat ukur yang digunakan dalam suatu mengukur apa yang diukur. Suatu kuesioner dikatakan valid jika pertanyaan pada kuesioner mampu untuk mengungkapkan sesuatu yang akan diukur oleh kuesioner tersebut (Wahyuni, 2014). Reliabilitas berasal dari bahasa Inggris yaitu reliability. Reliabilitas adalah alat untuk mengukur suatu kuesioner yang merupakan indikator dari peubah atau konstruk (Ghozali, 2009). Suatu kuesioner dikatakan reliabel atau handal jika jawaban seseorang terhadap pernyataan adalah konsisten atau stabil dari waktu ke waktu. Pengukuran yang memiliki reliabilitas yang tinggi adalah pengukuran yang dapat menghasilkan data yang reliable (Wahyuni, 2014).

\section{Hasil Penelitian}

Pengolahan data penelitian dimulai dengan pengujian validitas data penelitian dan uji reliabilitas data penelitian. Uji validitas untuk melihat instrumen penelitian, khususnya pernyataan atau pertanyaan dalam kuisioner penelitian layak atau tidak untuk mewakili variabel yang diteliti. Sedangkan uji reliabilitas untuk melihat konsistensi jawaban dari responden, serius atau tidak dalam menjawab kuisioner penelitian. Uji validitas diuji dengan melihat hasil dari outer model serperti dibawah ini.

Gambar 2. Hasil Outer Model

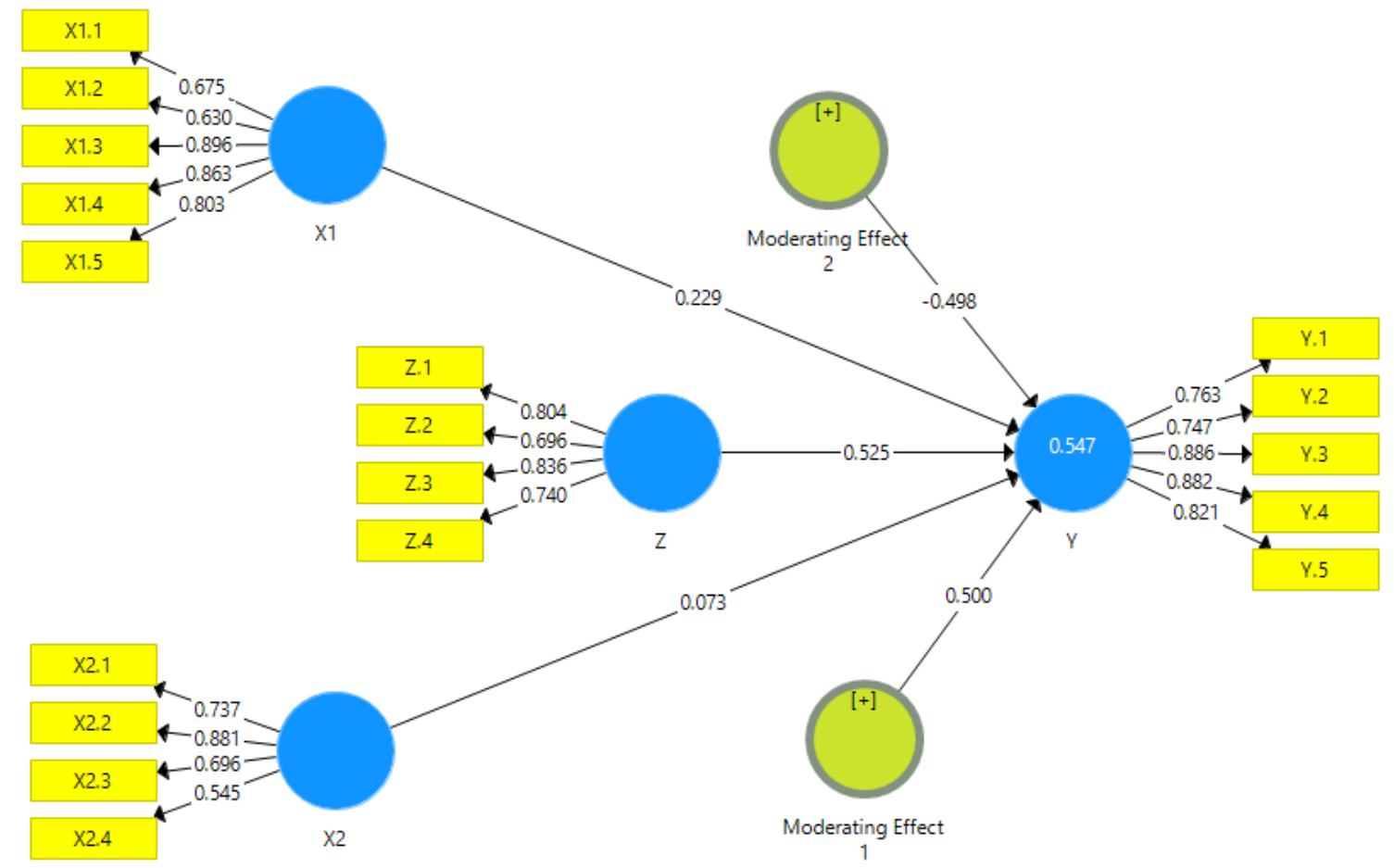

Keterangan: Technology Acceptance Model (X1), Digital Taxation (X2), Kepatuhan Wajib Pajak (Y), dan Pemahaman Internet (Z)

Hasil Outer Model di atas semuanya menunjukkan angka di atas 0,5. Hal ini berarti bahwa semua indikator telah valid. Maka dapat disimpulkan bahwa semua indikator variabel penelitian adalah sah. Selanjutnya dilakukan uji reliabilitas yang bermanfaat untuk mengetahui konsistensi dari responden penelitian. Hasilnya dapat dilihat pada tabel dibawah ini.

Tabel 3 


\begin{tabular}{|l|r|r|r|r|}
\hline & Cronbach's Alpha & rho_A & Composite Reliability & Average Variance Extracted (AVE) \\
\hline Moderating Effect 1 & 1.000 & 1.000 & 1.000 & 1.000 \\
\hline Moderating Effect 2 & 1.000 & 1.000 & 1.000 & 1.000 \\
\hline X1 & 0.856 & 0.913 & 0.884 & 0.609 \\
\hline X2 & 0.724 & 0.791 & 0.811 & 0.525 \\
\hline Y & 0.879 & 0.890 & 0.912 & 0.676 \\
\hline Z & 0.771 & 0.771 & 0.854 & 0.594 \\
\hline
\end{tabular}

Keterangan: Technology Acceptance Model (X1), Digital Taxation (X2), Kepatuhan Wajib Pajak (Y), dan Pemahaman Internet (Z)

Reliabilitas data dapat dilihat dari nilai yang ada pada cronbach's alpha, nilai rho, dan nilai composite reliability dengan ketentuan masing-masing score yang dihasilkan minimal 0,7. Selanjutnya nilai AVE juga bisa digunakan sebagai dasar untuk menilai reliabilitas jawaban dari responden, yakni bila hasil AVE > 0,5 maka dianggap reliabel.

Selanjutnya dilakukan pengujian terhadap lima hipotesis dalam penelitian ini dapat dilihat pada Tabel 4. Pengujian hipotesis pertama, pengaruh technology acceptance model (X1) terhadap kepatuhan wajib pajak (Y) adalah tidak signifikan dengan T-Statistik 1,931 < 1,96 dan P Values nya 0,054 > 0,05. Meskipun Original Sample adalah positif tetapi dampak yang diberikan oleh Technology acceptance model terhadap Kepatuhan wajib pajak tidak signifikan. Dengan demikian hipotesis pertama ditolak. Hal ini bertolak belakang dengan penelitian Sari et al (2014) dan Sudrajat \& Ompusunggu (2015) yang menyatakan bahwa technology acceptance model (X1) memiliki hubungan positif signifikan dengen Kepatuhan wajib pajak.

Tabel 4. Hasil Pengujian Hipotesis

\begin{tabular}{|l|r|r|r|r|r|} 
& Original Sample (O) & Sample Mean (M) & Standard Deviation (STDEV) & T Statistics (|O/STDEV|) & P Values \\
\hline Moderating Eff... & 0.500 & 0.443 & 0.190 & 0.009 \\
\hline Moderating Eff... & -0.491 & -0.484 & 0.182 & 0.629 \\
\hline X1 $\rightarrow$ Y & 0.250 & 0.280 & 0.129 & 0.007 \\
\hline X2 $\rightarrow$ Y & 0.068 & 0.086 & 0.147 & 0.054 \\
\hline$Z \rightarrow Y$ & 0.526 & 0.513 & 0.151 & 0.404 \\
\hline
\end{tabular}

Keterangan: Technology Acceptance Model (X1), Digital Taxation (X2), Kepatuhan Wajib Pajak (Y), dan Pemahaman Internet (Z)

Pengujian hipotsis kedua, pengaruh digital taxation (X2) terhadap kepatuhan wajib pajak (Y) tidak signifikan dengan T-Statistik $0,465<1,96$ dan $P$ Values nya $0,642>0,05$. Nilai Original Sample adalah positif, tetapi tidak memberikan dampak yang signifikan. Dengan demikian hipotesis kedua ditolak. Hasil penelitian ini bertolak belakang dengan hasil penelitian dari Sarunan (2015) dan Tambun \& Kopong (2017) Tambun \& Witriyanto (2016) yang menyatakan bahwa digital taxation memiliki pengaruh prositif signifikan terhadap Kepatuhan wajib pajak.

Pengujian hipotesis ketiga, pengaruh pemahaman Internet $(Z)$ terhadap kepatuhan wajib pajak (Y) adalah positif signifikan dengan T-Statistiknya 3,480 > 1,96 dengan P Values nya $0,001<0,05$. Nilai Original Sample adalah positif yaitu 0,526 yang menunjukkan arah hubungan Pemahaman Internet dengan Kepatuhan wajib pajak adalah positif. Dengan 
demikian hipotesis ketiga diterima. Hasil penelitian ini sejalan dengan hasil penelitian dari Istianita (2016) yang menyatakan bahwa Pemahaman Internet berpengaruh positif serta signifikan terhadap Kepatuhan wajib pajak.

Pengujian hipotesis keempat, moderasi pemahaman internet $(\mathrm{Z})$ atas pengaruh technology acceptance model (X1) terhadap kepatuhan wajib pajak (Y). Hasilnya menunjukkan pada kolom T-Statistik 2,629 > 1,96 dengan P Values 0,009 < 0,05. Maka dapat disimpulkan bahwa Pemahaman Internet mampu memoderasi secara signifikan pengaruh dari Technology acceptance model terhadap Kepatuhan wajib pajak. Nilai Original Sample menunjukkan nilai positif yang berarti variabel Pemahaman Internet memperkuat pengaruh Technology acceptance model terhadap Kepatuhan wajib pajak. Dengan demikian hipotesis keempat diterima. Hasil penelitian ini mendukung hasil penelitian dari Ngurah \& Putra (2019) yang menyatakan bahwa Pemahaman Internet mampu memoderasi pengaruh technology acceptance model terhadap Kepatuhan wajib pajak.

Pengujian hipotesis kelima, moderasi pemahaman internet $(\mathrm{Z})$ atas pengaruh digital taxation (X2) terhadap kepatuhan wajib pajak (Y). Hasil menunjukkan T-Statistik 2,704 > 1,96 dengan $\mathrm{P}$ Values $0,007<0,05$. Maka dapat disimpulkan bahwa Pemahaman Internet sebagai variabel moderating mampu memoderasi secara signifikan pengaruh dari digital taxation terhadap Kepatuhan wajib pajak. Nilai Original Sample menunjukkan nilai negatif yang berarti variabel Pemahaman Internet memperlemah pengaruh digital taxation terhadap Kepatuhan wajib pajak. Dengan demikian hipotesis kelima diterima. Hasil dari penelitian ini sesuai dengan hasil penelitian Mendra (2017) yang menyatakan bahwa Pemahaman Internet mampu memoderasi pengaruh digital taxation terhadap Kepatuhan wajib pajak.

\section{KESIMPULAN}

Hasil penelitian ini menunjukkan bahwa technology acceptance model dan digital taxation tidak berpengaruh signifikan terhadap kepatuhan wajib pajak. Pemahaman internet berpengaruh signifikan terhadap kepatuhan wajib pajak. Moderasi pemahaman internet mampu memoderasi (memperkuat) pengaruh technology acceptance model terhadap kepatuhan wajib pajak. Moderasi pemahaman internet mampu memoderasi (memperlemah) pengaruh digital taxation terhadap kepatuhan wajib pajak. Hal ini berarti technology acceptance model dan digital taxation tidak bisa berdiri sendiri untuk berdampak terhadap kepatuhan wajib pajak. Dibutuhkan dukungan pemahaman internet dari para wajib pajak. Hal ini juga memberi makna bahwa pemahaman internet sangat penting dan berperan sangat sentral untuk membangun kepatuhan wajib pajak. Pembuktian peran pemahaman internet ini turut mendukung konsistensi dari teori perilaku terencana. Perilaku patuh dipengaruhi oleh pemahaman pemahaman yang dimiliki wajib pajak, termasuk pemahaman dibidang internet. Hasil ini merekomendasikan betapa pentingnya internet untuk memberikan edukasi kepada wajib pajak, dimana hal tersebut berdampat terhadap kepatuhan wajib pajak. Saran bagi peneliti selanjutnya diantaranya mencari wilayah penelitian karena dalam penelitian ini hanya terbatas pada Wajib Pajak Orang Pribadi di wilayah Jakarta Utara yang menjalankan usaha dan pekerjaan bebas. Penelitian terbatas pada metode survey tanpa diikuti interview secara langsung. Saran bagi fiskus adalah lebih menggalakkan pemahaman internet karena mampu meningkatkan Kepatuhan wajib pajak. 


\section{DAFTAR PUSTAKA}

Ersania, G. A. R., \& Merkusiwati, N. K. L. A. (2018). Pengaruh Penerapan E-system Perpajakan Terhadap Tingkat Kepatuhan Wajib Pajak Orang Pribadi. E-Jurnal Akuntansi. https://doi.org/10.24843/eja.2018.v22.i03.p09

Fauzie, A., \& Wardani, D. K. (2016). The Influence Of Application Of Modernization In Taxation Administration System Toward The Level Of Tax Payer Compliance (Study Of KPP Pratama Bantul Individual Tax Payers). Jurnal Akuntansi. Https://Doi.Org/10.24964/Ja.V2i1.27

Handayani, K. R., \& Tambun, S. (2016). Pengaruh penerapan sistem e-filing dan pengetahuan perpajakan terhadap kepatuhan wajib pajak dengan sosialisasi sebagai variabel moderating (Survei pada Perkantoran Sunrise Garden di Wilayah Kedoya, Jakarta Barat). Media Akuntansi Perpajakan, 1(2), 59-73.

Istianita, R. (2016). Pengaruh Penerapan Sistem E-Filing Dan Pemahaman Internet Terhadap Kepatuhan Wajib Pajak Pada KPP Pratama Jakarta Cakung Dua. Universitas Bhayangkara.

Karmila. (2016). Pengaruh Tam Terhadap Kepatuhan Wajib Pajak Dengan Penggunaan EFiling Sebagai Variabel Intervening Pada Kpp Pratama Sukoharjo. Retrieved From Http://Eprints.Ums.Ac.Id/42031/1/Naskah Publikasi.Pdf

Kementrian Keuangan Republik Indonesia. (2018). Laporan Kinerja Direktorat Jenderal Perpajakan.

Kepatuhan Meningkat, Penyampaian SPT Tumbuh Double Digit. (2018). Retrieved from http://www.pajak.go.id/sites/default/files/SP- 19 Update SPT 31 Maret 2018.pdf

Lado, Y. O., \& Budiantara, M. (2018). Pengaruh Penerapan Sistem E-Filling Terhadap Kepatuhan Wajib Pajak Orang Pribadi Pegawai Negeri Sipil Dengan Pemahaman Internet Sebagai Variabel Pemoderasi ( Studi Kasus Pada Dinas Perindustrian Dan Perdagangan Diy). Jurnal Riset Akuntansi Mercu Buana, 4(1), 59-84. https://doi.org/10.26486/jramb.v4i1.498

Mendra, N. P. Y. (2017). Penerapan Sistem E-Filing, Kepatuhan Wajib Pajak Dan Pemahaman Internet. Jurnal Riset Akuntansi, 7, 222-234.

Ngurah, I. G., \& Putra, A. (2019). Pengaruh Penerapan E-Filling Pada Kepatuhan WPOP Pegawai Negeri Sipil Dengan Pemahaman Internet Sebagai Variabel Pemoderasi. E$\begin{array}{lll}\text { Jurnal } \quad \text { Akuntansi, } & 28, & 262-269 .\end{array}$ https://doi.org/https://doi.org/10.24843/EJA.2019.v28.i01.p10

Oktaviani, R. M., Sunarto, S., \& Lita, N. (2018). Pemahaman Internet Sebagai Pemoderasi Penerapan Sistem E-Filling Terhadap Kepatuhan Wajib Pajak. Prosiding SENDI_U 2018, 575-580.

Pemerathna, A. H. S. (2017). Economic Impact of Digital taxation: A Case on Information Communication Technology Industry Sri Lanka. SSRN Electronic Journal. https://doi.org/10.2139/ssrn.2910328

Project, B., Project, B., Framework, I., Framework, I., Arising, T. C., Framework, I., ... Framework, I. (2020). Tax and digitalisation. (March 2019).

Sari, N. P., Kertahadi, \& NP, Nm. G. W. E. (2014). Pengaruh Penerapan e-SPT Terhadap 
Kepatuhan Wajib Pajak Badan Dalam Melaporkan SPT (Studi Kasus Pada KPP Madya Malang). 1-10. Retrieved from http://perpajakan.studentjournal.ub.ac.id/index.php/perpajakan/article/viewFile/25/22

Sarunan, W. (2015). Pengaruh Modernisasi Sistem Administrasif Perpajakan Terhadap Kepatuhan Wajib Pajak Orang Pribadi Dan Wajib Pajak Badan Pada Kantor Pelayanan Pajak Pratama Manado. Jurnal Riset Ekonomi, Manajemen, Bisnis Dan Akuntansi.

Sifile, O., Kotsai, R., Mabvure, J. T., \& Chavunduka, D. (2018). Effect of e-tax filing on tax compliance: A case of clients in Harare, Zimbabwe. African Journal of Business Management. https://doi.org/10.5897/ajbm2018.8515

Sudrajat, A., \& Ompusunggu, A. P. (2015). Pemanfaatan teknologi Informasi , Sosialisasi Pajak, Pengetahuan Perpajakan, dan Kepatuhan wajib pajak. Jurnal Riset Akuntansi Dan Perpajakan JRAP Universitas Pancasila, 2(2), 193-202.

Tambun, S., \& Kopong, Y. (2017). The Effect of E-Filing on The of Compliance Individual Taxpayer, Moderated By Taxation Socialization. South East Asia Journal of Contemporary Business, Economics and Law.

Tambun, S., \& Witriyanto, E. (2016). Pengaruh Kesadaran Wajib Pajak Dan Penerapan ESystem Terhadap Tingkat Kepatuhan Wajib Pajak Dengan Preferensi Resiko Sebagai Variabel Moderating (Studi Empiris Kepada Wajib Pajak Di Komplek Perumahan Sunter Agung Jakarta Utara). Media Akuntansi Perpajakan, 1(2), 86-94.

Wahyudi, M. (2009). Kajian Penerapan Sistem Informasi Karyawan Berbasis Web Berdasarkan Pendekatan TAM. Paradigma, XI(2), 156-170. 